\title{
Immunolocalization of steroidogenic enzymes in the corpus luteum and placenta of the Japanese black bear, Ursus thibetanus japonicus, during pregnancy
}

\author{
T. Tsubota ${ }^{1}$, S. Taki ${ }^{1}$, K. Nakayama ${ }^{1}$, J. I. Mason ${ }^{2}$, S. Kominami ${ }^{3}$, \\ N. Harada ${ }^{4}$ and I. Kita ${ }^{1}$ \\ ${ }^{1}$ Laboratory of Theriogenology, Faculty of Agriculture, Gifu University, Gifu 501-11, Japan; \\ ${ }^{2}$ University Department of Clinical Biochemistry, Royal Infirmary of Edinburgh NHS Trust, \\ Edinburgh, UK; ${ }^{3}$ Faculty of Integrated Arts and Sciences, Hiroshima University, Hiroshima \\ 730, Japan; and ${ }^{4}$ Molecular Genetics, Institute for Comprehensive Medical Science, School \\ of Medicine, Fujita-Gakuen Health University, Aichi 470-11, Japan
}

The Japanese black bear, Ursus thibetanus japonicus, is a seasonal breeder and shows delayed implantation for several months during pregnancy. The objective of this study was to clarify the steroidogenic capability of the corpus luteum and placenta during pregnancy, including both delayed implantation and fetal development, by immunolocalization of steroidogenic enzymes in these organs of the Japanese black bear. Ovaries and placentae from 15 wild Japanese black bears, which had been killed legally by hunters and were thought to be pregnant, were used in an immunocytochemical study to localize the cholesterol side chain cleavage cytochrome P450 (P450scc), 3ß-hydroxysteroid dehydrogenase (3ßHSD), 17 $\alpha$-hydroxylase cytochrome P450 (P450c17) and aromatase cytochrome P450 (P450arom) by the avidin-biotin-peroxidase complex method using polyclonal antisera raised in mammals against P450scc, 3BHSD, P450c17 and P450arom. P450scc and 3BHSD were localized in all luteal cells throughout pregnancy. P450c17 was present in a few luteal cells, especially in the outer area of the corpus luteum throughout pregnancy, but the

\section{Introduction}

The Japanese black bear, Ursus thibetanus japonicus, is a seasonal breeder and has a breeding season from mid-June to early August (Yamamoto et al., 1998) and a parturition period from late January to early February (Sato et al., 2000a). Hence, the gestation period of the Japanese black bear is approximately 6-7 months. However, during pregnancy, black bears show delayed implantation for several months until late November or early December (Tsubota et al., 1997), as do other members of the Ursidae

Email: tsubota@cc.gifu-u.ac.jp number of positively immunostained cells decreased during the post-implantation period. Cells positively immunostained for P450c17 were significantly smaller than negatively immunostained cells $(P<0.01)$. P450arom was present sporadically in a few luteal cells throughout pregnancy, but the number of positively immunostained cells decreased during the post-implantation period. The size of cells positively immunostained for P450arom was not significantly different from that of negatively immunostained cells. The whole placenta was negatively immunostained for P450scc, 3ßHSD and P450c17, but P450arom was present in the syncytiotrophoblasts and endothelial cells of maternal blood vessels. These results indicate that, in the Japanese black bear, corpora lutea are a source of progesterone which may play an important role in the maintenance of delayed implantation and fetal development during pregnancy. Corpora lutea have a minimum capability to synthesize androgen in small luteal cells and oestrogen in normal-sized luteal cells during pregnancy, and placentae have the ability to synthesize oestrogen during late pregnancy.
(European brown bears: Dittrich and Kronberger, 1963; American black bears: Daniel, 1974; Hokkaido brown bears: Tsubota and Kanagawa, 1993). The gestation period in Ursidae is divided into two phases: (i) delayed implantation as an early stage and (ii) fetal development as a late stage. During the period of delayed implantation, cell division of embryos ceases or development at the blastocyst stage is very slow, and the embryos float in the uterine lumen (Wimsatt, 1963; Tsubota et al., 1991; Tsubota and Kanagawa, 1993). After implantation, fetal development occurs over about 60 days (Tsubota et al., 1987), and one or two neonates are usually produced during the winter denning period (Tsubota et al., 1994).

The endocrinological features during the period of 
Table 1. Sampling dates and age of Japanese black bears, Ursus thibetanus japonicus

\begin{tabular}{cccl}
\hline Bear no. & Date of sampling & Age of bear (years) & \multicolumn{1}{c}{ Special remarks } \\
\hline 1 & $09 / 07 / 1992$ & Adult* & \\
2 & $15 / 07 / 1992$ & 4 & \\
3 & $00 / 07 / 1991$ & 7 & An unimplanted embryo was found \\
4 & $25 / 08 / 1985$ & 15 & \\
5 & $27 / 08 / 1982$ & 4 & \\
6 & $31 / 08 / 1993$ & 9 & \\
7 & $01 / 09 / 1993$ & 28 & \\
8 & $16 / 09 / 1984$ & Adult* & \\
9 & $19 / 09 / 1990$ & Adult* & A fetus was found \\
10 & $24 / 09 / 1992$ & 7 & A fetus (91 mm) was found and only the placenta \\
11 & $03 / 10 / 1991$ & 6 & was used for study \\
12 & $02 / 12 / 1991$ & 6 & A fetus (49 mm) was found \\
13 & $22 / 12 / 1991$ & Adult* & \\
14 & $06 / 01 / 1993$ & 16 &
\end{tabular}

*The age of the bears was unknown, but they were all sexually mature.

delayed implantation and fetal development in Ursidae have been examined in detail in American black bears (Foresman and Daniel, 1983; Hellgren et al., 1991) and Hokkaido brown bears (Tsubota et al., 1987, 1991). These studies indicate that peripheral progesterone concentrations fluctuate markedly during pregnancy, including the period of delayed implantation. Progesterone was maintained at relatively high concentrations during the period of delayed implantation, but increased markedly at peri-implantation and decreased abruptly to baseline concentrations at parturition. Oestrogen fluctuated erratically without a regular tendency in relation to delayed implantation. In bears, other pituitary and ovarian hormones, such as inhibin, prolactin, $\mathrm{FSH}$ and $\mathrm{LH}$, have been investigated by the measurement of the peripheral concentrations of these hormones (Tsubota et al., 1998; Sato et al., 2000a).

The objective of this study was to immunolocalize steroidogenic enzymes in the corpus luteum and placenta throughout pregnancy to determine whether the sites of steroidogenesis change as pregnancy progresses in Japanese black bears.

\section{Materials and Methods}

\section{Materials}

Ovaries containing corpora lutea, uteri and placentae (in one case (no. 14), the placenta only) were collected from 15 adult female Japanese black bears that had been killed legally by hunters between July 1984 and January 1993 in the central area of Honshu Island, Japan (Table 1). These tissues were removed within $24 \mathrm{~h}$ after the bears had been killed. A pre-implantation embryo, which was $0.7 \mathrm{~mm}$ in diameter and had developed to the blastocyst stage, was recovered from the uterine lumen of one bear (no. 6), and fetuses and placentae were obtained from three bears (nos
13, 14 and 15). The age of these bears was determined by counting the cementum annuali of the first premolar teeth, as described by Yoneda (1976).

\section{Immunocytochemistry}

After the ovaries and placentae were fixed in $4 \%(\mathrm{v} / \mathrm{v})$ formaldehyde solution, they were dehydrated with graded concentrations of ethanol and embedded in paraffin wax. Each paraffin wax section ( $5 \mu \mathrm{m}$ in thickness) was placed on poly-L-lysine-coated glass slides (Poly-prep ${ }^{\mathrm{TM}}$ slides, Sigma, St Louis, MO) and paraffin wax was removed using xylene. The sections were immunostained with antisera of cholesterol side chain cleavage cytochrome P450 (P450scc; from Dr S. Kominami), 3 3 -hydroxysteroid dehydrogenase (3ßHSD; from Dr J. I. Mason), $17 \alpha$-hydroxylase/ C17-C20 lyase cytochrome P450 (P450c17; from Dr S. Kominami) and aromatase cytochrome P450 (P450arom; from $\operatorname{Dr} \mathrm{N}$. Harada) using the avidin-biotin-peroxidase complex method described by Araki et al. (1996). Briefly, the sections were placed into methanol with $0.3 \%(\mathrm{v} / \mathrm{v})$ $\mathrm{H}_{2} \mathrm{O}_{2}$ (Wako) for 10 min to block endogenous peroxidase activity, incubated in PBS containing $10 \%(\mathrm{v} / \mathrm{v})$ normal goat serum (Sigma) for $10 \mathrm{~min}$ to reduce background staining and treated with primary antisera (1:500 or 2000) raised in rabbits against bovine adrenocortical mitochondrial P450scc (Suhara et al., 1978), human placental microsomal 3ßHSD (Doody et al., 1990), guinea-pig adrenal microsomal P450c17 (Kominami et al., 1982) and human placental microsomal P450arom (Harada, 1988). Thereafter, the sections were incubated with a second antibody, goat anti-rabbit IgG conjugated with biotin and peroxidase with avidin, using a rabbit ExtrAvidin ${ }^{\mathrm{TM}}$ staining kit (Sigma), followed by colouring with $30 \mathrm{mg}$ 3,3'-diaminobenzidine (Wako) solution in $150 \mathrm{ml}$ of $0.05 \mathrm{~mol}$ Tris- $\mathrm{HCl} \mathrm{l}^{-1}$ buffer, $\mathrm{pH}$ 7.6, plus $30 \mu \mathrm{H}_{2} \mathrm{O}_{2}$. Finally, the reacted sections were 
Table 2. Comparison of the size of luteal cells between positively and negatively immunostained for P450c17 and P450arom in 14 Japanese black bears, Ursus thibetanus japonicus

\begin{tabular}{|c|c|c|c|c|c|c|c|}
\hline \multirow{2}{*}{$\begin{array}{l}\text { Month of } \\
\text { sampling }\end{array}$} & \multirow[b]{2}{*}{ Bear no. } & \multicolumn{3}{|c|}{ P450c17 } & \multicolumn{3}{|c|}{ P450arom* } \\
\hline & & Positive & Negative & $P$ value & Positive & Negative & $P$ value \\
\hline \multirow[t]{3}{*}{ July } & 1 & $11.7 \pm 0.2$ & $17.0 \pm 0.3$ & $<0.01$ & $19.5 \pm 0.4$ & $20.5 \pm 0.5$ & NS \\
\hline & 2 & $13.1 \pm 0.2$ & $18.1 \pm 0.3$ & $<0.01$ & $22.1 \pm 0.5$ & $22.2 \pm 0.5$ & NS \\
\hline & 3 & $13.2 \pm 0.3$ & $18.5 \pm 0.3$ & $<0.01$ & $19.7 \pm 0.4$ & $20.9 \pm 0.5$ & NS \\
\hline \multirow[t]{3}{*}{ August } & 4 & $12.2 \pm 0.3$ & $19.4 \pm 0.3$ & $<0.01$ & $19.2 \pm 0.5$ & $20.2 \pm 0.5$ & NS \\
\hline & 5 & $13.7 \pm 0.3$ & $20.3 \pm 0.3$ & $<0.01$ & $20.7 \pm 0.5$ & $20.8 \pm 0.4$ & NS \\
\hline & 6 & $11.1 \pm 0.3$ & $17.2 \pm 0.3$ & $<0.01$ & $16.9 \pm 0.4$ & $17.3 \pm 0.3$ & NS \\
\hline \multirow{4}{*}{ September } & 7 & $10.7 \pm 0.2$ & $18.4 \pm 0.3$ & $<0.01$ & $18.6 \pm 0.5$ & $19.0 \pm 0.4$ & NS \\
\hline & 8 & $12.5 \pm 0.2$ & $21.5 \pm 0.3$ & $<0.01$ & $\mathrm{~N}$ & N & \\
\hline & 9 & $11.0 \pm 0.2$ & $17.2 \pm 0.3$ & $<0.01$ & $\mathrm{~N}$ & $\mathrm{~N}$ & \\
\hline & 10 & $14.0 \pm 0.3$ & $18.5 \pm 0.3$ & $<0.01$ & $19.9 \pm 0.5$ & $18.6 \pm 0.3$ & NS \\
\hline October & 11 & $10.7 \pm 0.2$ & $17.7 \pm 0.3$ & $<0.01$ & $\mathrm{~N}$ & N & \\
\hline \multirow[t]{2}{*}{ December } & $12^{*}$ & $12.9 \pm 0.4$ & $22.1 \pm 0.5$ & $<0.01$ & $\mathrm{~N}$ & $\mathrm{~N}$ & \\
\hline & 13 & ND & ND & & ND & ND & \\
\hline January & 15 & ND & ND & & $24.7 \pm 0.8$ & $22.9 \pm 0.5$ & NS \\
\hline
\end{tabular}

Values are mean $\pm \mathrm{SE}$.

A total of 100 positively and negatively immunostained cells were measured randomly for size by determining the square root of long diameter $\times$ short diameter. *The size of 50 cells was measured because of the small population of cells for immunostaining.

$\mathrm{N}$ : all cells were negatively immunostained: ND: the size of cells was not measured because of the small population of cells for immunostaining; NS: not significant.

counterstained with haematoxylin solution (Merck). The control sections were treated with normal rabbit serum (Sigma) instead of the primary antisera.

\section{Measurement of the size of luteal cells}

A total of 50 or 100 luteal cells, immunostained positively and negatively for P450c17 and P450arom, were selected randomly and measured using a micrometer in an eyepiece. The size of the cells was expressed by determining the square root of the long diameter $\times$ short diameter (in $\mu \mathrm{m}$ ). Luteal cells with P450c17 immunostaining in bears 13 and 15 and with P450arom immunostaining in bear 13 were not measured because there were insufficient positively immunostained cells. Statistical analysis was performed using the Student's $t$ test.

\section{Results}

\section{Gross and histological observation}

All ovaries contained corpora lutea, primary, secondary, antral and atretic follicles and interstitial tissue. The corpora lutea contained connective tissue in the central area and luteal cells were arranged radially around the connective tissue. There were two types of luteal cell: one with large clear nuclei and the other with small pale nuclei, although there were only a few cells with small pale nuclei (Fig. 1a). Cells that had large clear nuclei were distributed throughout the corpora lutea, but cells with small pale nuclei were present only in the outer region of the corpora lutea. Corpora lutea were judged to be steroidogenically active because of the marked vacuolation in the cytoplasm of luteal cells (Fig. 1a) as described by Tsubota and Kanagawa (1993).

Three of the 15 bears had placentae, which from gross characteristics were observed to be of the zonary type and were classified histologically as the endotheliochorial type. The maternal placenta is composed of three zones. Maternal capillaries were connected to the syncytiotrophoblast of the fetal placenta (Fig. 2a).

\section{Immunocytochemical studies}

Control sections for both the corpus luteum and the placenta were negatively stained except for the counterstaining of nuclei with haematoxylin (Fig. 1a). In most of the bears, P450scc and 3 3 HSD were localized in the cytoplasm of all luteal cells throughout pregnancy (Fig. $1 \mathrm{~b}, \mathrm{c}$, respectively). P450c17 was present in a few luteal cells, especially in the outer area of the corpus luteum throughout pregnancy (Fig. $1 \mathrm{~d}, \mathrm{e}$ ), but the number of positively immunostained cells tended to decrease during the post-implantation period. Cells that were positively immunostained for P450c17 were significantly smaller than negatively immunostained cells $(P<0.01)$ (Table 2$)$. P450arom was sporadically present in a few luteal cells in the corpora lutea throughout pregnancy (Fig. 1e), but the number of positively immunostained cells decreased significantly during the post-implantation period $(10.6 \pm 1.0 \%$ in delayed implantation period versus $1.6 \pm 1.1 \%$ in postimplantation period; $P<0.01$ ). The size of cells positively immunostained for P450arom was not significantly different from that of negatively immunostained cells (Table 2). 

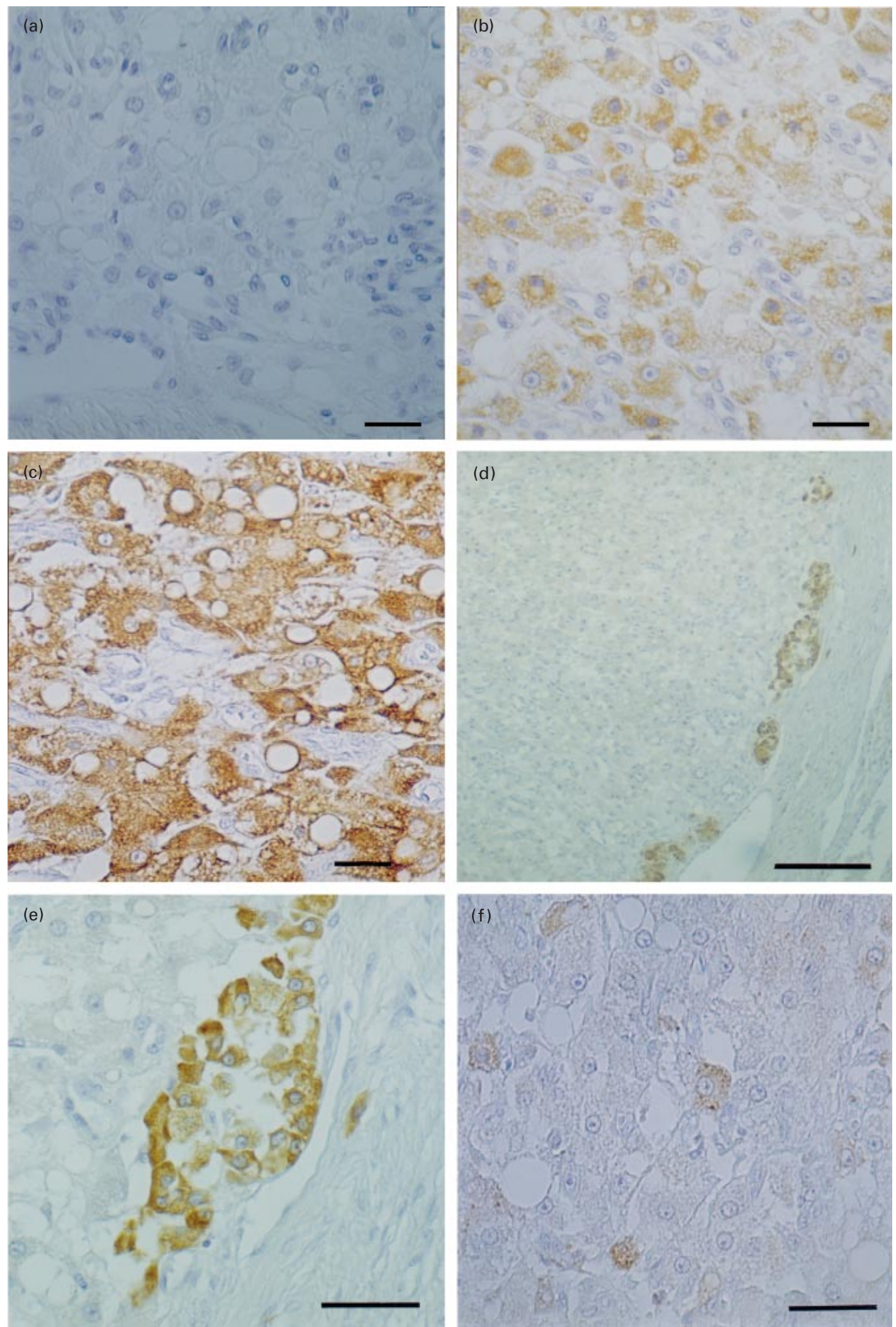

Fig. 1. Typical histological appearance (bear no. 2) of sections of corpora lutea from Japanese black bears, Ursus thibetanus japonicus, during delayed implantation. All sections were stained with haematoxylin as a counterstain. (a) Control incubated with normal rabbit serum in place of a primary antibody. There were two types of luteal cell: cells with large clear nuclei and cells with small pale nuclei. (b) Immunostaining for 
The whole placenta was negatively immunostained for P450scc, 33HSD and P450c17, but P450arom was present in the syncytiotrophoblast and endothelial cells of maternal blood vessels (Fig. 2).

\section{Discussion}

In the present study, three of 15 Japanese black bears had placentae, whereas the other 12 bears were assumed to be undergoing delayed implantation. Unimplanted embryos of $0.7 \mathrm{~mm}$ in diameter were detected in the uterus of only one of 12 bears sampled during the presumed period of delayed implantation, because the uteri were fixed in formaldehyde solution before they were flushed to recover embryos. However, it is assumed that the bears with corpora lutea in their ovaries had unimplanted embryos in the uterine lumen because: (i) these samples were collected at the time when delayed implantation usually occurs in Hokkaido brown bears (Tsubota and Kanagawa, 1993); (ii) luteal cells contained steroidogenic enzymes indicating that these cells were steroidogenically active (Tsubota et al., 1994); and (iii) the uterine glands had numerous tall epithelial cells, which are indicative of delayed implantation (Tsubota and Kanagawa, 1993).

This immunocytochemical study showed that all luteal cells of Japanese black bears contained P450scc and $3 \beta \mathrm{HSD}$ during and after the period of delayed implantation. P450scc, which converts cholesterol to pregnenolone in the mitochondria of luteal cells, is a rate-limiting enzyme for luteal steroidogenesis (Carr, 1992). 33HSD converts pregnenolone to progesterone via the $\Delta 4$ steroidogenic pathway. Results from the present study indicate that, throughout the period of delayed implantation and after delayed implantation, the corpora lutea of Japanese black bears synthesize progesterone from cholesterol using P450scc and 3 $\beta$ HSD.

Progesterone production in the corpus luteum during delayed implantation has been reported in western spotted skunks (Ravindra et al., 1984), ferrets (Kintner and Mead, 1983) and badgers (Fevold and Wright, 1969). The present study is also supported by reports that peripheral progesterone concentrations increase from undetectable concentrations during the pre-mating season to relatively high concentrations during the period of delayed implantation, remain high at the time of implantation and decrease to baseline values before parturition in Japanese black bears (Sato et al., 2000b), Hokkaido brown bears (Tsubota et al., 1987) and American black bears (Foresman and Daniel, 1983; Hellgren et al., 1991). Furthermore, the study on Hokkaido brown bears demonstrated that all luteal cells contained P450scc and 3ßHSD during the delayed implantation period, indicating that corpora lutea synthesize progesterone during this period (Tsubota et al., 1994).

P450c17 and P450arom convert progesterone to androgen, and androgen to oestrogen, respectively. In the present study, only a few luteal cells in 13 of 14 bears and 12 of 14 bears contained P450c17 and P450arom, respectively, indicating that the corpus luteum has a minimum capability to synthesize androgen and oestrogen, respectively. There are also no reports that peripheral androgen and oestrogen concentrations increase during the period of delayed implantation in bears. Tsubota et al. (1994) suggested that P450c17 and P450arom are contained in two separate cell populations, which would mean that each cell population has the ability to synthesize either androgen or oestrogen, but not both hormones. The present study supports this hypothesis because the cells that contained P450c17 were distributed in the outer region of the corpus luteum, whereas P450arom-positive cells were dispersed throughout the corpus luteum. In addition, P450c17-positive cells were smaller than P450arom-positive cells. Hence, the corpus luteum in the Japanese black bear consists of three types of cell, which synthesize progesterone only and progesterone plus androgen and oestrogen, but androgen and oestrogen synthesis is low during the period of delayed implantation.

The corpora lutea of many mammals contain two distinct steroidogenic cell populations, commonly called small and large luteal cells. However, in carnivores, only one type of luteal cell, presumably derived from granulosa cells, has been reported (Mossman and Duke, 1973). In ferrets (Joseph and Mead, 1988) and western spotted skunks (Sinha and Mead, 1975) it is assumed that luteal cells are derived from granulosa cells, even though large and small luteal cells have been observed. Whether carnivores, including bears, have two types of luteal cell that are derived from different original cells remains to be determined.

In brown and black bears, peripheral progesterone concentrations are high during the peri-implantation period (Foresman and Daniel, 1983; Tsubota et al., 1987; Hellgren et al., 1991; Sato et al., 2000b). This observation indicates that, in bears, the corpus luteum is reactivated after receiving stimulation from either the pituitary or another gland at the time of implantation. In American black bears, the size of the corpus luteum and each luteal cell increases at implantation (Wimsatt, 1963). In the present study, although the size of the luteal cells tended to increase after implantation, no difference was observed in the immunostaining of the corpora lutea pre- and post-implantation. A quantitative analysis of $3 \beta \mathrm{HSD}$, the key enzyme for progesterone synthesis, and its mRNA is required.

cholesterol side chain cleavage cytochrome P450 (P450scc). All luteal cells were positively immunostained. (c) Immunostaining for $3 \beta$-hydroxysteroid dehydrogenase (3ßHSD). All luteal cells were positively immunostained. (d) Immunostaining for $17 \alpha$-hydroxylase cytochrome P450 (P450c17) at a low magnification. A few luteal cells, especially in the outer area of the corpus luteum, were positively immunostained. (e) Immunostaining for P450c17 at high magnification. (f) Immunostaining for aromatase cytochrome P450 (P450arom). A few luteal cells were positively immunostained. Scale bars represent (a-c,e,f) $50 \mu \mathrm{m}$, (d) $200 \mu \mathrm{m}$. 

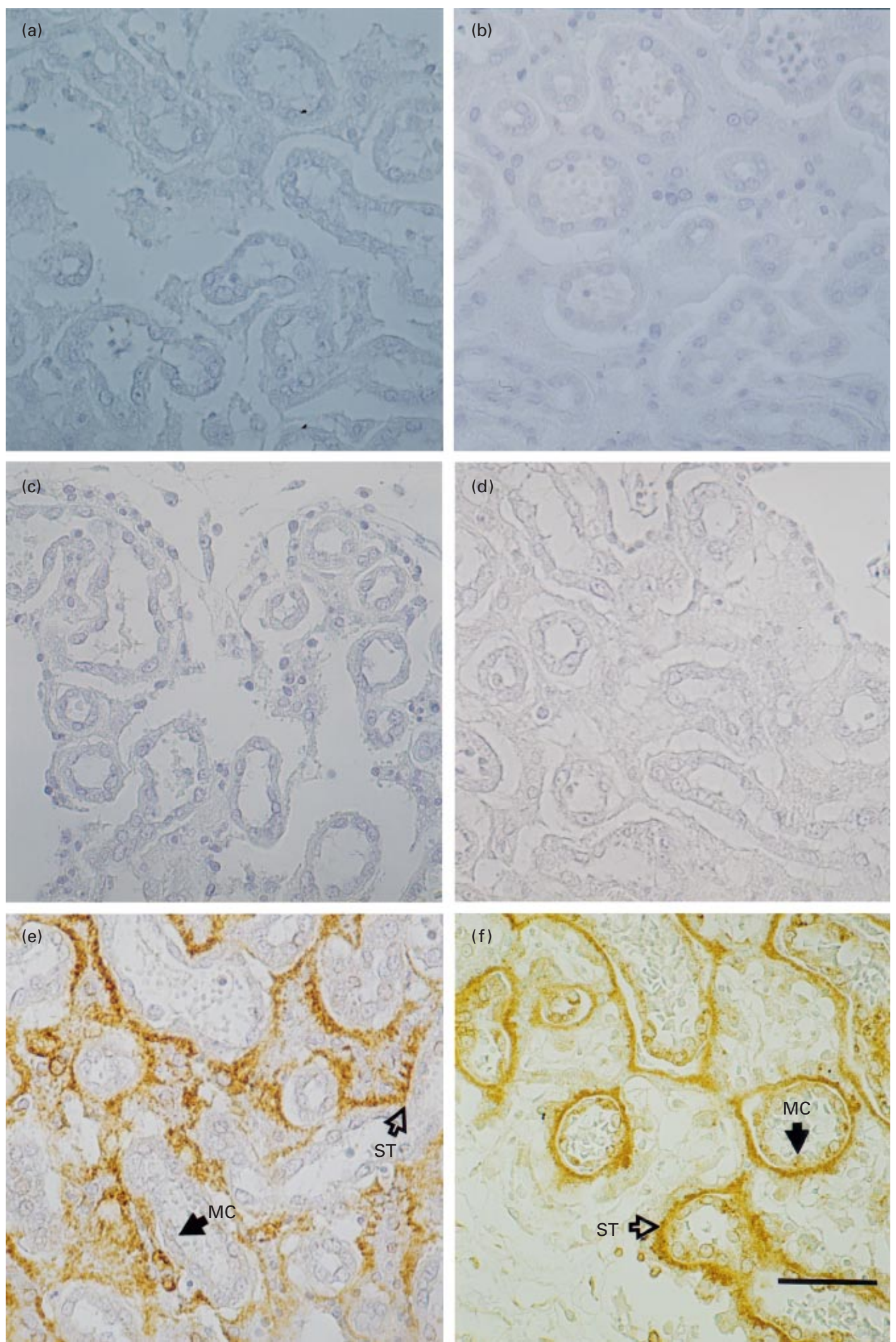

Fig. 2. Typical histological appearance (a-e: bear no. 15; f: bear no. 14) of sections of placentae from Japanese black bears, Ursus thibetanus japonicus, during fetal development. All sections were stained with haematoxylin as a counterstain. (a) Control incubated with normal rabbit serum in place of a primary antibody. The maternal capillaries were directly connected to the cytotrophoblast or the syncytiotrophoblast. (b) Immunostaining for 
In some mammalian species, progesterone and oestrogen secreted from the placenta are involved in the maintenance of pregnancy and the induction of parturition; however, the type and concentration of these hormones differs among species. P450arom, the key enzyme in converting androgen to oestrogen, was present in the syncytiotrophoblast of the labyrinthine zone of the placenta in all three bears that had fetuses and placentae. Furthermore, in two of the three bears, P450arom was also immunolocalized in the endothelial cells of maternal blood vessels. This finding indicates that the placenta, including the syncytiotrophoblast and the endothelial cells, can synthesize oestrogen. There are some reports on humans and domestic cats in which P450arom was immunolocalized in syncytiotrophoblast (Sasano, 1989; Zhong et al., 1989; Naganuma et al., 1990), and 33HSD, but not P450arom, was present in the endothelial cells of maternal blood vessels in ferrets (Ferguson and Christie, 1967). The source of androgen as a precursor of oestrogen synthesis in the placenta varies among animals. It is possible that androgen is supplied by the fetus since P450c17 was absent in the placenta.

In conclusion, this immunocytochemical study indicates that, in Japanese black bears, corpora lutea are a source of progesterone which may play an important role in the maintenance of delayed implantation and fetal development during pregnancy; corpora lutea have a minimum capability to synthesize androgen in small luteal cells and oestrogen in normal-sized luteal cells during pregnancy; and placentae can synthesize oestrogen throughout pregnancy.

This study was supported by Grants-in-Aid for Research from the Ministry of Education, Science and Culture, Japan (nos 10306020 and 07760299).

\section{References}

Araki H, Tsubota T, Maeda N, Harada N, Kominami S, Mason JI and Kita I (1996) Intraovarian immunolocalization of steroidogenic enzymes in a Hokkaido brown bear, Ursus arctos yesoensis, during the mating season Journal of Veterinary Medical Science 58 787-790

Carr BR (1992) Disorders of the ovary and female reproductive tract. In Williams Textbook of Endocrinology 8th Edn pp 733-798 Eds JD Wilson and DW Foster. Saunders, Philadelphia

Daniel JC, Jr (1974) Conditions associated with embryonic diapause during reproduction in the black bear Second Eastern Workshop on Black Bear Management and Research 4 1-45

Dittrich L and Kronberger H (1963) Biologische-Anatomische Untersuchungen uber die Fortpflanzungs-biologie des Braunbaren und anderer Ursiden in Gefangenschaft Zeitschrift fur Saugetierkunde 28 129-155 (in German with English summary)

Doody KM, Carr BR, Reiney WE, Byrd W, Murry BA, Stricker RC, Thomas JL and Mason JI (1990) 3ß-hydroxysteroid dehydrogenase/isomerase in the fetal zone and neocortex of the human fetal adrenal gland Endocrinology 126 2487-2492

Ferguson MM and Christie GA (1967) Distribution of hydroxysteroid dehydrogenases in the placenta and foetal membranes of various mammals Journal of Endocrinology 38 291-306

Fevold HR and Wright PL (1969) Steroid metabolism by badger (Taxidea taxus) ovarian tissue homogenates General and Comparative Endocrinology 13 60-67

Foresman KR and Daniel JC, Jr (1983) Plasma progesterone concentrations in pregnant and non-pregnant black bears Journal of Reproduction and Fertility 68 235-239

Harada N (1988) Novel properties of human placental aromatase as cytochrome P-450: purification and characterization of a unique form of aromatase Journal of Biochemistry 103 106-113

Hellgren EC, Vaughan MR, Gwazdauskas FC, Williams B, Scanlon PF and Kirkpatrick RL (1991) Endocrine and electrophoretic profiles during pregnancy and nonpregnancy in captive female black bears Canadian Journal of Zoology 69 892-898

Joseph MM and Mead RA (1988) Size distribution of ferret luteal cells during pregnancy Biology of Reproduction 39 1159-1169

Kintner PJ and Mead RA (1983) Steroid metabolism in corpus luteum of the ferret Biology of Reproduction 29 1121-1127

Kominami S, Shinzawa K and Takemori S (1982) Purification and some properties of cytochrome P450 specific for steroid $17 \alpha$-hydroxylation and $\mathrm{C} 17-\mathrm{C} 20$ bond cleavage in pig adrenal microsomes Biochemical and Biophysical Research Communications 109 916-921

Mossman HW and Duke KL (1973) Comparative Morphology of the Mammalian Ovary University of Wisconcin Press, Madison

Naganuma H, Ohtani H, Harada N and Nagura H (1990) Immunoelectron microscopic localization of aromatase in human placenta and ovary using microwave fixation Journal of Histochemistry and Cytochemistry 38 1427-1432

Ravindra R, Bhatia K and Mead RD (1984) Steroid metabolism in corpora lutea of the western spotted skunk (Spilogale putorius latifrons) Journal of Reproduction and Fertility 72 495-502

Sasano H (1989) Immunolocalization of aromatase, $17 \alpha$-hydroxylase and side-chain-cleavage cytochromes P450 in human ovary Journal of Reproduction and Fertility 85 163-169

Sato M, Nakano N, Tsubota T, Komatsu T, Murase T, Kita I and Kudo T (2000a) Changes in serum progesterone, estradiol-17 $\beta$, luteinizing hormone and prolactin in lactating and non-lactating Japanese black bears Journal of Reproduction and Development 46 301-308

Sato M, Tsubota T, Yamamoto K, Komatsu T, Hashimoto Y, Katayama A, Hazumi T, Kita I and Kudo T (2000b) Serum progesterone and estradiol$17 \beta$ concentrations in captive and free-ranging adult female Japanese black bears (Ursus thibetanus japonicus) Journal of Veterinary Medical Science 62 415-420

Sinha AA and Mead RA (1975) Ultrastructural changes in granulosa lutein cells and progesterone levels during preimplantation, implantation and early placentation in the western spotted skunk Cell and Tissue Research 164 179-192

Suhara K, Gomi T, Sato H, Itagaki E, Takemori S and Katagiri M (1978) Purification and immunochemical characterization of the two adrenal cortex mitochondrial cytochrome P450-proteins Archives of Biochemistry and Biophysics $190290-299$

Tsubota T and Kanagawa H (1993) Morphological characteristics of the ovary, uterus and embryo during the delayed implantation period in the Hokkaido brown bear (Ursus arctos yesoensis) Journal of Reproduction and Development 39 325-331

cholesterol side chain cleavage P450 (P450scc). All placental cells were negatively immunostained. (c) Immunostaining for 3ß-hydroxysteroid dehydrogenase $(3 \beta \mathrm{HSD})$. All placental cells were negatively immunostained. (d) Immunostaining for $17 \alpha$-hydroxylase cytochrome P450 (P450c17). All placental cells were negatively immunostained. (e) Immunostaining for aromatase cytochrome P450 (P450arom) in a bear with a fetus of $49 \mathrm{~mm}$ in crown-rump length (CRL). The syncytiotrophoblast was positively immunostained. (f) Immunostaining for P450arom in a bear with a fetus of $91 \mathrm{~mm}$ in CRL. The syncytiotrophoblast and endothelial cells of maternal capillaries were positively immunostained. MC: maternal capillaries; ST: syncytiotrophoblast. Scale bar represents $50 \mu \mathrm{m}$. 
Tsubota T, Takahashi $\mathbf{Y}$ and Kanagawa H (1987) Changes in serum progesterone levels and growth of fetuses in Hokkaido brown bear International Conference of Bear Research and Management 7 355-358

Tsubota T, Takahashi Y, Kanagawa H and Gohda K (1991) Embryo recovery during delayed implantation in the captive Hokkaido brown bear, Ursus arctos yesoensis. Journal of Veterinary Medical Science 53 141-142

Tsubota T, Nitta H, Osawa Y, Mason JI, Kita I, Tiba T and Bahr JM (1994) Immunolocalization of steroidogenic enzymes, P450scc, 3ßHSD, P450c17 and P450arom in the corpus luteum of the Hokkaido brown bear (Ursus arctos yesoensis) in reference to delayed implantation Journal of Reproduction and Fertility 101 557-561

Tsubota T, Taki S, Nakayama K, Mason JI, Kominami S, Harada N and Kita I (1997) Immunolocalization of steroidogenic enzymes in the corpus luteum and the placenta of Japanese black bears, Ursus thibetanus japonicus, during pregnancy Biology of Reproduction $\mathbf{5 6}$ Supplement 190

Tsubota T, Howell-Skalla L, Boone WR, Garshelis DL and Bahr JM (1998) Serum progesterone, estradiol, luteinizing hormone and prolactin profiles in the female black bear (Ursus americanus) Animal Reproduction Science 53 107-118

Wimsatt WA (1963) Delayed implantation in the Ursidae, with particular reference to the black bear. In Delayed Implantation pp 49-86 Ed. AC Enders. University of Chicago Press, Chicago

Yamamoto K, Tsubota T and Kita I (1998) Observation of sexual behavior of captive Japanese black bears, Ursus thibetanus japonicus. Journal of Reproduction and Development 44 13-18 (in Japanese with English summary)

Yoneda M (1976) Age determination and age structure of the Ezo brown bear Journal of Mammalogical Society of Japan 10 165-167 (in Japanese)

Zhong C, Ishimura K, Yoshinaga-Hirabayashi T, Fujita H, Kitawaki J and Osawa Y (1989) Immunocytochemical study on the localization of aromatase in the ovary of golden hamster, guinea pig and cow Acta Histochemica et Cytochemica-Kyoto 22 501-507

Manuscript received 6 July 2000.

First decision 8 September 2000.

Revised manuscript received 10 November 2000.

Accepted 17 November 2000. 